\title{
How students' achievement goals shape their beliefs about effective teaching: A 'build-a-professor' study
}

\author{
Corwin Senko, Kimberly Belmonte and Anastasyia Yakhkind \\ State University of New York-New Paltz, New York, USA
}

Background. Which instructor qualities do students consider most important? The answer likely depends on the student. This study attempted to trace beliefs about the most essential instructor qualities to students' academic achievement goals.

Aims. The present study tested the hypothesis that students pursuing mastery goals favour instructors who stimulate and challenge them intellectually, whereas those pursuing performance goals favour instructors who present material clearly and provide clear cues about how to succeed.

Sample. Participants were I57 students at a 4-year public university.

Method. Participants designed the ideal professor through a hypothetical combination of nine widely valued instructor qualities, such as enthusiasm, presentation clarity, and an interactive teaching style. The more they acquired of any one instructor quality, the less they could acquire of the others, thus compelling students to distinguish necessary qualities from desirable luxury qualities.

Results. Students' achievement goals corresponded to their views about the most essential instructor qualities. Mastery goals predicted greater demand for professors who intellectually challenge students and possess topic expertise, whereas performance goals predicted high demand for professors who present material clearly and provide cues about how to succeed in the course.

Conclusions. The findings support emerging theorizing about how mastery and performance goals nudge students to pursue different learning agendas, with distinct consequences to their learning experience.

Students surely want their teachers to be enthusiastic, knowledgeable, clear, caring, and so forth, but which qualities do they prize most? That is, which do students consider absolutely necessary and which do they consider mere 'luxury items'? The answer likely depends in part on the individual student's goal(s) for the course (McKeachie, 1997; Murphy, Cleveland, Skattebo, \& Kinney, 2004). We pursued this possibility in the current study, using achievement goal theory as the guiding framework.

*Correspondence should be addressed to Corwin Senko, Department of Psychology, SUNY New Paltz, 600 Hawk Drive, New Paltz, NY I256I, USA (e-mail: senkoc@newpaltz.edu). 


\section{Achievement goal theory}

Students pursue various goals in their coursework (Ford, 1992). Achievement goal theory spotlights two of them: mastery goals and performance goals (Ames, 1992; Dweck \& Elliott, 1983; Nicholls, 1984). Mastery goals students focus on developing competence, skills, and topic knowledge. Success and failure are determined with either task-based standards (e.g., solving $90 \%$ of the problems) or, more commonly, intrapersonal standards (e.g., personal judgment of one's improvement or quality of learning). Performance goals instead focus students on outperforming peers. Success and failure are determined, therefore, with interpersonal standards, typically on criteria established by teachers. Theorists (Elliot \& McGregor, 2001; Pintrich, 2000) eventually posited that both goals can also be framed in an avoidance manner (i.e., a 'mastery-avoidant goal' to avoid failing to learn, or a 'performance-avoidant goal' to avoid being outperformed by others), but the current research will focus squarely on the approach forms of these goals because they are more germane to the 'learning agenda' postulate described later in the paper.

Goal theory posits that mastery goals match or surpass performance goals in producing educational benefits (Ames, 1992; Dweck \& Elliott, 1983; Nicholls, 1984). Ample research has tested this broad hypothesis (for reviews, see Hulleman, Schrager, Bodmann, \& Harackiewicz, 2010; Moller \& Elliot, 2006; Payne, Youngcourt, \& Beaubien, 2007). It has linked mastery goals to many benefits, such as hope and confidence (Pekrun, Elliot, \& Maier, 2006), interest in the course material (Harackiewicz, Durik, Barron, Linnenbrink-Garcia, \& Tauer, 2008), 'deep' learning strategies that include elaboration and synthesis of course material (Elliot, McGregor, \& Gable, 1999), metacognition and self-regulation (Wolters, 1998), willingness to seek help (Karabenick, 2003), cooperativeness (Harris, Yuill, \& Luckin, 2008), and self-efficacy and effort (Bong, 2005). Yet, there has been a surprising exception to this pattern of benefits: mastery goals are seldom linked to actual achievement, typically defined by exam score or course grades (see Hulleman et al., 2010, for a meta-analysis of over 200 education studies). Performance goals, by contrast, have generally been linked to a much narrower set of outcomes. Some are negative, such as the use of 'surface' learning strategies that rely on rote memorization (Elliot et al., 1999), hindered cooperative learning (Harris et al., 2008), and openness to cheating (Van Yperen, Hamstra, \& van der Klauw, 2011). Other outcomes are more positive. For example, performance goals promote positive emotions such as pride (Pekrun et al., 2006), self-efficacy and effort (Bong, 2005), and, importantly, high achievement in the classroom (see Hulleman et al., 2010).

In sum, it appears that mastery goals provide many benefits that, curiously, do not translate regularly into achievement. Equally strange, performance goals do appear to aid achievement despite also promoting surface learning strategies, which usually have null or negative links to achievement (Senko, Hulleman, \& Harackiewicz, 2011). This pattern of goal relationships with achievement was never anticipated by goal theory's founders, and therefore compels theorists to identify the reasons for these effects. One emerging explanation is that mastery and performance goals nudge students to pursue distinct learning agendas that in turn affect achievement.

\section{Learning agendas fostered by achievement goals}

The learning agenda explanation traces to how mastery goals and performance goals define success. Performance goals typically define success with normative criteria set by 
the course instructor. ${ }^{1}$ These criteria are often rigid and challenging (Dweck \& Elliott, 1983; Elliot, 2005). According to Senko and Miles (2008), these goals therefore obligate students to identify and follow the teacher's learning agenda. That is, performancefocused students must remain vigilant for cues (e.g., the teacher's demands, hints, study guides) about the topic knowledge and skills, which the teacher values and is likely to assess on exams and assignments, and then study those topics faithfully. This strategic approach may sometimes boost their performance on course assignments and tests (Diseth \& Martinsen, 2003). Mastery goals, by contrast, typically define success with student-based criteria, whether improvement on one's own work or even just a subjective sense of having learned the course material sufficiently. These criteria are inherently more flexible and negotiable, thus allowing greater feelings of control in one's efforts to succeed (Dweck \& Elliott, 1983; Elliot, 2005). Mastery goals may therefore allow students greater freedom to pursue their own learning agenda. That is, mastery-focused students are better positioned to focus on satisfying their curiosities about the course material. This 'interest-based studying' approach should facilitate deep learning of the personally interesting topics, though perhaps to the neglect of any personally duller material that their teacher tests. In sum, performance goals may be more apt than mastery goals to direct students toward studying the instructionally important material, and this may help explain the goal relationships with achievement.

Recent studies support this learning agenda explanation. Senko and Miles (2008) found that mastery-focused students reported allotting more study time to the personally interesting topics, sometimes to the neglect of the duller topics also tested. This interestbased studying strategy in turn predicted low exam performance. Performance-focused students, by contrast, disavowed that study strategy and earned high grades in the class. Similarly, other studies indicate that performance-focused students, relative to masteryfocused students, report being more attentive to instructor cues and guidance about which topics to study (Shell \& Husman, 2008; Vermettten, Lodewijks, \& Vermunt, 2001), and are also more likely to struggle on unstructured tasks (Escribe \& Huet, 2005). Finally, Poortvliet, Janssen, Van Yperen and Van de Vliert (2007) provided experimental evidence that performance goals may increase students' vigilance for taskrelated cues. Participants in their study exchanged preliminary ideas with a confederate about the possible solutions to a problem, and then submitted their final solutions to the experimenter. Those assigned performance goals, relative to those assigned a mastery goal, incorporated into their solutions more of the strong ideas and fewer of the weak ideas from the confederate.

The current research provides an additional, novel test of the learning agenda premise. Our guiding assumption is that performance and mastery goals lead students to prefer teaching styles that facilitate the pursuit of these distinct agendas. Specifically, if performance-focused students do in fact pursue their teacher's learning agenda, then they should prize teachers who provide clear cues about this agenda (i.e., clues about which material is most important to learn for assignments and exams, and useful tips on how to

\footnotetext{
I Theorists are debating about the core feature of performance goals. Some contend that it is a striving to demonstrate ability (e.g., Grant \& Dweck, 2003). Others contend that it is a striving to outperform peers (e.g., Eliot, 2005). This distinction is not trivial. A recent meta-analysis found that performance goals focused on outperforming others produce positive relationships with achievement, whereas those focused on demonstrating competence produce negative relationships (Hulleman et al., 2010). Because the hypotheses for the current study are rooted to the positive link between performance goals and achievement, we focus on the competitive type of performance goal throughout this paper. Readers interested in a fuller review of the debate are directed to Elliot (2005), Hulleman et al. (2010), and Sideridis (2009).
} 
succeed) and present material in a clear and structured manner that allows for direct note taking and comprehension. By contrast, if mastery-focused students do pursue their own interests, then they should prize instructors who help arouse and sustain their interest in the course material. Interest is not a singular construct, however, so it is important to consider the types of interest most relevant here. Hidi and Renninger (2006) distinguish between situational interest and individual interest. Situational interest is triggered by attention-grabbing cues in the situation, such as a teacher's enthusiasm and use of entertainment (e.g., humour, anecdotes, or fun videos). If maintained and bolstered by a belief that the topic is personally useful, it can develop into individual interest, which is characterized by students exploring the material to satisfy their personal curiosities. Of the two, individual interest is more strongly associated with mastery goal pursuit and use of deep learning strategies (Harackiewicz et al., 2008), and is also instrumental in triggering interest-based studying (Senko \& Miles, 2008). We propose, then, that mastery-focused students prize instructors who possess ample topic expertise and skill at challenging students intellectually, both of which help cultivate and sustain students' individual interest in the course material.

Note that these postulates are not intended to imply that students devalue other instructor qualities. Most performance-focused students and mastery-focused students would surely desire that their teachers also be warm and compassionate, provide a reasonable workload, engage students in discussion, and so on. Yet they should consider these and other teacher qualities to be luxuries, not necessities. The current study tests this proposal.

\section{Distinguishing necessary versus luxury instructor qualities}

Necessities, by definition, are essential items, whereas luxuries are highly desirable items sought only after obtaining satisfactory amounts of the necessities. Distinguishing necessary instructor qualities from luxury qualities is methodologically tricky. Likerttype measures are insufficient because they allow individuals to consider the qualities independently; as most students would 'want it all' from their instructors, they would likely give high ratings of importance to many desirable teacher qualities. We instead needed a methodology that compels students to compare and, importantly, make tradeoffs between different teacher qualities. Ordinal ranking procedures are somewhat better suited to this task, of course, but they too are flawed because they conceal the amount of spread between ranked items and therefore cannot distinguish necessities from luxuries. For example, a student's 2nd and 3rd ranked instructor qualities could both be 'necessities' with little separating them in importance, or the 2 nd could represent a necessity and the 3rd a luxury to the student.

We therefore adopted Li and colleague's (Li, Kenrick, Bailey, \& Linsenmeier, 2002) budget paradigm for distinguishing necessities from luxuries in trait judgments. This method entails having participants design an ideal person (e.g., a mate, a friend, or an employee) using multiple hypothetical 'budgets', ranging from low-to-high spending power, with which to purchase various attributes. The more that people spend on one attribute (e.g., kindness), the less they have leftover to spend on other attributes (e.g., intelligence or sense of humour). In this way, they must carefully consider which attributes are absolutely necessary when given the low budget, and then they can spend increasingly more on luxury items when given a higher spending budget. We tailored this method to our research question by having students build their ideal professor. 
Table I. Description of the nine professor qualities

\begin{tabular}{|c|c|}
\hline \multicolumn{2}{|r|}{ The professor ... } \\
\hline Enthusiastic/Entertaining: & $\begin{array}{l}\text { Is energetic and enjoys the topic. Uses humour, anecdotes, and } \\
\text { other methods to keep you engaged. }\end{array}$ \\
\hline Intellectually challenging: & $\begin{array}{l}\text { Encourages rigorous thinking about the material. Forces you to go } \\
\text { beyond the basics. }\end{array}$ \\
\hline Topic expertise: & $\begin{array}{l}\text { Is very knowledgeable about the material. Answers questions } \\
\text { competently. Explains how course topics are similar or } \\
\text { different to ideas in related fields of study. }\end{array}$ \\
\hline Clear about how to succeed: & $\begin{array}{l}\text { Is clear about what students must do to succeed. Conveys which } \\
\text { material is most important to study when preparing for exams } \\
\text { and assignments. }\end{array}$ \\
\hline Clear presentation style: & $\begin{array}{l}\text { Presents material clearly. Summarizes well. Gives good examples. } \\
\text { Style of lecturing makes it easy to take notes. }\end{array}$ \\
\hline Reasonable workload: & $\begin{array}{l}\text { Gives a reasonable workload. Spaces out assignments so that } \\
\text { students are not overworked. }\end{array}$ \\
\hline Interactive teaching style: & $\begin{array}{l}\text { Welcomes class discussion. Encourages students to express their } \\
\text { opinions. Invites students to disagree. }\end{array}$ \\
\hline Warm/Compassionate personality: & $\begin{array}{l}\text { Is friendly toward individual students. Easy to approach. Shows } \\
\text { compassion. }\end{array}$ \\
\hline Good feedback: & $\begin{array}{l}\text { Gives helpful feedback (beyond merely a grade) so that you can } \\
\text { learn and improve. }\end{array}$ \\
\hline
\end{tabular}

Instructor qualities were culled from two primary sources. The first is Feldman's $(1976,1988)$ influential reviews of prior research in which students report the characteristics of superior teachers. He identified approximately 20 characteristics. The second source is Marsh's $(1984,1991)$ factor analytic work that reduced Feldman's list to nine broad dimensions of effective teaching. His measure of these qualities remains the most extensively validated and widely used measure of teaching effectiveness. It also provides foundation for the nine instructor qualities used in this study: being enthusiastic and entertaining in ways that trigger situational interest; intellectually challenging students in ways that stimulate curiosity and deepen their learning; possessing sufficient topic expertise to facilitate deep learning; providing clear cues about how to succeed in class; using a clear presentation style that facilitates note taking; providing a reasonable workload; offering useful feedback to students; using an interactive teaching style; and having a warm personality and rapport with students (see Table 1). We excluded from this list the extraneous factors that either are relatively peripheral to the teacher, such as the usefulness of homework assignments, or that can bias instructor ratings, such as the complexity of course readings or the difficulty of getting a high grade (Greenwald \& Gillmore, 1997a, 1997b). ${ }^{2}$

\footnotetext{
2 Our list of instructor qualities aligns nicely with Marsh's (1984). There are three minor differences between them. One is that we excluded his homework assignments dimension, as noted. Another is that we split his examination dimension into two subcategories, one concerning quality of feedback and the other clarity about how to succeed, because we theorized that the achievement goals would lead students to value them differently. The third is that our Warmth/Compassion quality mirrors his individual rapport but omits mention of accessibility outside of class, because that quality is less vital to students than warmth and approachability (Feldman, 1976).
} 


\section{Hypotheses}

In sum, we hypothesized that students who pursue performance goals, relative to those who do not, will deem clarity about how to succeed in the class and clarity of presentation to both be necessities. We hypothesized that students who pursue mastery goals, relative to those who do not, will instead deem intellectual challenge and topic expertise to be necessities in their professors. We expected that the remaining qualities would be considered either luxury items or unimportant qualities for students pursuing either of the goals.

These hypotheses concern the distinct relations of mastery or performance goals with spending on instructor qualities. It is also possible, of course, that some students pursue both goals (Barron \& Harackiewicz, 2001; Bouffard, Vezeau, \& Bordeleau, 1998). Perhaps those students spend differently under low budget constraints than students pursuing only a mastery goal or a performance goal. They might, for example, spend primarily on teacher qualities relevant to the two goals (i.e., Intellectual Challenge, Clarity about How to Succeed) and neglect the remaining qualities when allocating their necessity budget. We will explore this possibility as well by testing for multiple goal effects.

\section{Method}

\section{Participants and procedure}

Participants were 157 (120 female, 37 male; 80\% Caucasian) students at a 4-year public university. Most were Psychology majors (87\%) participating to fulfil a requirement of the major; the rest were non-psychology majors participating for extra credit in an elective psychology course. The sample included mostly juniors (40\%) and seniors (43\%), and, according to their self-reports, averaged a 3.20 cumulative Grade Point Average $(S D=$ $0.41)$ at the time of participation.

Participants completed a survey packet comprising the build-a-professor task, achievement goal measures, and demographic questions. They did either a paper version $(n=$ $36)$ or an identical online version $(n=121)$ of the survey during the second half of the semester. Preliminary results showed no difference in effects based on version, so the data from each were combined for the final analyses.

\section{The build-a-professor task}

The survey packet explained that participants' task was to design their ideal professor. They were provided a list and description of nine qualities that students often say they value in professors (see Table 1), and were asked to combine them in a way that they consider ideal. The order of instructor qualities was randomized. To facilitate this process, participants were given hypothetical budgets with which to 'purchase' amounts of the nine instructor qualities. Next to each quality was a purchasing scale ranging from $\$ 0$ to $\$ 10$, the maximum amount they could spend on any given quality. Participants were instructed to design their ideal instructor by spending their full budget in a manner that demonstrates how valuable they consider each quality. For clarification, they were further told, 'The more money you spend on a quality, the more valuable you consider it. For example, if you spend $\$ 6$ on enthusiasm and $\$ 2$ on clarity, you are essentially saying that you value enthusiasm much more than clarity'.

Participants did this task three times, first with a $\$ 20$ budget, then with a $\$ 40$ budget, and finally with a $\$ 60$ budget. The $\$ 20$ budget condition is the most important one 
because it compels students to prioritize necessities. For example, if participants were to spend $\$ 9$ on enthusiasm, they would have only $\$ 11$ leftover for the remaining eight teacher qualities. In the sizable $\$ 60$ budget condition, by contrast, they would still have $\$ 51$ leftover to purchase any remaining luxury items they desire.

\section{Achievement goal measures}

Students completed modified versions of the mastery-approach goal (e.g., 'My goal is to learn as much as possible in my classes') and performance-approach goal (e.g., 'My goal is to perform better than the other students in my classes') measures from the Achievement Goal Questionnaire-Revised (Elliot \& Murayama, 2008; alphas > .90 for both 3 -item goal measures). The original measures focus students on a specific course. Our modification instead focused students on their current courses in general because our research question concerns students' beliefs about the ideal teaching style, regardless of the course (for a similar approach, see Remedios \& Lieberman, 2008). Participants rated each goal item on a 1 (strongly disagree) to 5 (strongly agree) scale.

\section{Results}

Our first set of analyses explored which professor qualities students deemed necessities. The second explored which qualities they deemed luxuries. The third tested our hypotheses about the relationships of mastery and performance goals to those student judgments.

\section{Which instructor qualities are necessities?}

The budget methodology relies on the microeconomic principle that people prioritize necessary items when constrained by a small budget, but then spend increasingly more on luxury items as they acquire additional disposable income. To identify necessities, we compared the funding given to each of the nine qualities with the constrained $\$ 20$ budget (Necessity Budget). Necessities are those qualities which receive significantly more of this budget than the other qualities (Li et al., 2002). For example, if students spend 20\% (\$4) of this Necessity budget on 'intellectual challenge' and $10 \%(\$ 2)$ on each of the remaining eight qualities, the intellectual challenge quality could be deemed a greater necessity. Table 2 provides each quality's mean allocation (in the form of percentage of the $\$ 20$ budget).

A repeated-measure analysis of variance (ANOVA) on students' spending with the Necessity budget revealed that students did prioritize some qualities over others, $F(8$, $1,240)=22.53, p<.001$, eta $^{2}=.13$, with considerable range in the amount of money allocated to the qualities (i.e., $16.77 \%$ vs. $7.16 \%$ ). Students spent most on Enthusiasm/ Entertainment $(M=16.77 \%, S D=9.51)$, followed closely by Topic Expertise, Clarity About How to Succeed, a Clear Presentational Style, and a Reasonable Workload, thus designating each relatively necessary instructor qualities. They considered Good Feedback $(M=7.33 \%, S D=5.38)$ and an Interactive Teaching Style $(M=7.16 \%, S D=$ 6.13) the least essential. 
Table 2. Professor qualities and mean (and SD) percentages of money allocated towards necessary versus luxury qualities

\begin{tabular}{lccc}
\hline Professor qualities & $\begin{array}{c}\text { Necessity budget } \\
\text { (Ist set of \$20) }\end{array}$ & $\begin{array}{c}\text { Luxury budget } \\
(3 \text { rd set of \$20) }\end{array}$ & $\begin{array}{c}\text { Change in } \\
\text { spending }\end{array}$ \\
\hline Enthusiastic/Entertaining: & $16.77 \%^{\mathrm{a}}$ & $12.29 \%^{\mathrm{ab}}$ & $-4.48 \%^{* * *}$ \\
Intellectually challenging: & $9.83 \%^{\mathrm{c}}$ & $8.85 \%^{\mathrm{c}}$ & $-0.98 \%$ \\
Topic expertise: & $12.80 \%^{\mathrm{b}}$ & $10.41 \%^{\mathrm{abc}}$ & $-2.39 \%^{*}$ \\
Clear about how to succeed: & $12.98 \%^{\mathrm{bc}}$ & $10.30 \% \mathrm{bc}$ & $-2.68 \%^{*}$ \\
Clear presentation style: & $11.80 \%^{\mathrm{bc}}$ & $12.24 \%^{\mathrm{abc}}$ & $+0.44 \%$ \\
Reasonable workload: & $11.73 \%^{\mathrm{bc}}$ & $11.07 \%^{\mathrm{abc}}$ & $-0.66 \%$ \\
Interactive teaching style: & $7.16 \%^{\mathrm{d}}$ & $10.18 \%^{\mathrm{abc}}$ & $+3.02 \%^{* * *}$ \\
Warm/Compassionate personality: & $9.60 \%^{\mathrm{c}}$ & $12.91 \%^{\mathrm{ab}}$ & $+3.31 \%^{* *}$ \\
Good feedback: & $7.33 \%^{\mathrm{d}}$ & $11.66 \%^{\mathrm{abc}}$ & $+4.33 \%^{* * *}$ \\
\hline
\end{tabular}

Notes. $N=157$. For each column, mean values with unshared subscripts differ significantly, $p<.05$. For change in spending measure, ${ }^{*} p<.05,{ }^{* *} p<.01$, ${ }^{* * *} p<.001$.

\section{Which instructor qualities are luxuries?}

We sought next to learn how students appraised the non-necessary qualities. Are they desirable luxuries or simply unimportant? To answer this, we followed Li et al.'s (2002) procedure for distinguishing luxury qualities from unimportant qualities. This entailed, for each instructor quality, subtracting the money allocated to it in the medium budget (\$40) from the amount allocated to it in the high budget (\$60). This is similar to asking participants how they would allocate an additional $\$ 20$ dollars after they have already spent $\$ 40$ (and therefore have likely purchased their necessities). We compared students' spending patterns with this final \$20 (Luxury Budget) to the pattern with their first $\$ 20$ (Necessity Budget). To be considered a luxury, an instructor quality must receive significantly more funding from the final $\$ 20$ than from the first $\$ 20 .{ }^{3}$ Qualities that instead receive small funding with both budgets would be considered relatively unimportant. For example, suppose students allocated only $10 \%$ of their Necessity budget toward 'good feedback'. If they significantly increased this allocation (e.g., 25\%) with the Luxury budget, this quality would be considered a luxury item.

A repeated-measure ANOVA on students' spending with the Luxury budget revealed an overall difference between instructor qualities, $F(8,1,240)=2.72, p<.01$, eta ${ }^{2}=$ .02 , but the effect was small and due solely to students spending less on Intellectual Challenge $(M=8.85 \%, S D=7.94)$ than Enthusiasm/Entertainment $(M=12.29 \%, S D=$ $9.01)$ or a Warm Personality $(M=12.91 \%, S D=9.52)$. No other pair of qualities received significantly different money allocations (see Table 2). Moreover, the range of spending with the Luxury budget (4.09\%) was much smaller than it was with the Necessity budget (9.61\%), which is consistent with the economics assumption that a luxury budget allows greater opportunity to purchase all commodities considered desirable but of secondary importance.

To designate an instructor quality as a luxury, however, requires a comparison of the amounts spent on it under the Necessity budget versus Luxury budget. Pairwise

\footnotetext{
3 Whereas classification as a luxury requires low funding under low budget conditions and increased funding under higher budgets, classification as a necessity merely requires relatively high funding under low budget, with either maintained or decreased funding under higher budgets (Li et al., 2002).
} 
comparisons, summarized in Table 2 (see the Change in Spending column), showed that students spent relatively small amounts of their Necessity budget on an Interactive Teaching Style, Warmth/Compassion, and providing Good Feedback, but then spent significantly more on each when given the higher budget. Thus, these qualities can each be classified as a luxury item for this sample. Finally, none of the remaining qualities received such small funding in each budget that it could be characterized as unimportant to participants.

\section{Goal relationships with spending patterns}

Our main research question concerns how achievement goals shape students' beliefs about the most necessary instructor qualities. We hypothesized that students pursuing performance goals would deem Clarity About Success and Clear Presentation Skill necessities, but that those pursuing mastery goals would deem Intellectual Challenge and Topic Expertise to be necessities. We therefore examined the relationships the two goals had with spending patterns under Necessity versus Luxury budget conditions. Necessities are indicated by a significant positive relationship between a goal and the money spent on an instructor quality under the Necessity budget. At the other extreme, relatively unimportant qualities are indicated by significant negative correlations between a goal and quality in botb budgets. Finally, luxuries are revealed by (a) a null or negative relationship between the goal and quality under the Necessity budget, along with (b) a significant and positive increase in the relationship under the Luxury budget. Testing for luxuries required creating a new measure (Spending Change) that captures differences in spending between the two budgets. For each quality, we therefore subtracted the amount of funding it received in the Necessity budget from the amount received in the Luxury budget; the more positive this score, the more the students deemed the instructor quality a luxury item.

Three sets of regression analyses were conducted, each utilizing a model that comprised the two goals and, in order to explore multiple goal effects, the Mastery $\mathrm{X}$ Performance interaction term. The performance goal $(M=3.58, S D=1.21)$ and mastery goal $(M=4.33, S D=1.06)$, which were uncorrelated $(r=.10, p>.20)$, were standardized (Judd, 2000). The first set of analyses tested how goals predict spending on each instructor quality with the Necessity budget. The next set did the same for spending with the Luxury Budget. The final set did the same for the new Spending Change measure. Table 3 provides the results.

Matching our hypotheses, these analyses reveal that the more strongly students pursued performance goals, the more of their Necessity budget they allocated to a professor who is Clear about How to Succeed $(\beta=.17)$ and who has a Clear Presentation Style that allows for easy note taking $(\beta=.16)$. In both cases, this was more than was allocated to those qualities under the Luxury Budget (Spending Change $\beta s=-.19$ and -.17 , respectively). Thus, both qualities qualified as necessities to students pursuing performance goals. These same students also spent increasingly more of their Luxury budget than their Necessity budget on an Interactive Teaching Style $(\beta s=.21)$ and providing Good Feedback $(\beta s=.20)$, thus designating each as luxuries. Performance goal pursuit was unrelated to spending on the remaining five instructor qualities.

Mastery goals had a different pattern of effects. As hypothesized, the more strongly students pursued mastery goals, the more of their Necessity budget they spent on Intellectual Challenge $(\beta s=.30)$ and Topic Expertise (Spending Change $\beta s=.30$ and .18 , respectively). In both cases, this was significantly more than they spent of their Luxury budget (Spending Change $\beta s=-.24$ and -.23 , respectively). Both therefore 
Table 3. Regression analyses of goal relationships with spending towards each instructor quality

\begin{tabular}{|c|c|c|c|c|}
\hline \multirow[b]{2}{*}{ Professor quality } & Performance goal & Mastery goal & Performance $\mathrm{X}$ mastery & $F$-value, $R^{2}$ \\
\hline & \multicolumn{4}{|c|}{ Necessity budget } \\
\hline Enthusiasm: & .07 & .05 & -.15 & $1.06, .02$ \\
\hline $\begin{array}{l}\text { Intellectual } \\
\text { challenge: }\end{array}$ & -.02 & $.30^{* * *}$ & .01 & $5.06, .09^{* *}$ \\
\hline $\begin{array}{l}\text { Clarity about } \\
\text { Success: }\end{array}$ & $.17^{*}$ & -.13 & .01 & $2.4 \mathrm{I}, .04 \dagger$ \\
\hline Topic expertise: & -.14 & $.18^{*}$ & .08 & $2.73, .05^{*}$ \\
\hline Clear presentation: & $.16^{*}$ & -.12 & -.05 & $2.36, .04 \dagger$ \\
\hline $\begin{array}{l}\text { Reasonable } \\
\text { workload: }\end{array}$ & .10 & $-.21^{*}$ & -.10 & $3.20, .06^{*}$ \\
\hline Interactive style: & $-.24^{* *}$ & -.01 & .13 & $2.67, .05^{*}$ \\
\hline Warm personality: & -.02 & -.02 & .13 & $1.25, .02$ \\
\hline \multirow[t]{2}{*}{ Good feedback: } & $-.16 \dagger$ & -.10 & -.02 & $2.34, .04$ \\
\hline & \multicolumn{4}{|c|}{ Luxury budget } \\
\hline Enthusiasm: & -.01 & -.02 & .07 & $0.23, .00$ \\
\hline $\begin{array}{l}\text { Intellectual } \\
\text { challenge: }\end{array}$ & .00 & -.04 & .00 & $0.06, .00$ \\
\hline $\begin{array}{l}\text { Clarity about } \\
\text { Success: }\end{array}$ & -.11 & $.25^{* *}$ & .00 & $3.62, .07^{*}$ \\
\hline Topic expertise: & -.10 & $-.16^{*}$ & .11 & $1.91, .04$ \\
\hline Clear presentation: & -.08 & -.12 & .10 & $1.13, .02$ \\
\hline $\begin{array}{l}\text { Reasonable } \\
\text { workload: }\end{array}$ & .01 & .05 & .11 & $0.93, .02$ \\
\hline Interactive style: & .09 & .10 & -.16 & $1.43, .03$ \\
\hline Warm personality: & .04 & -.02 & -.06 & $0.20, .00$ \\
\hline \multirow[t]{2}{*}{ Good feedback: } & .14 & -.05 & -.14 & $\mathrm{I} .4 \mathrm{I}, .03$ \\
\hline & \multicolumn{4}{|c|}{ Change in spending } \\
\hline Enthusiasm: & -.05 & -.05 & .14 & $0.91, .02$ \\
\hline $\begin{array}{l}\text { Intellectual } \\
\text { challenge: }\end{array}$ & .02 & $-.24^{* *}$ & -.01 & $2.99, .06^{*}$ \\
\hline $\begin{array}{l}\text { Clarity about } \\
\text { success: }\end{array}$ & $-.19 *$ & $.26^{* *}$ & .00 & $5.18, .09^{* *}$ \\
\hline Topic expertise: & .03 & $-.23^{* *}$ & .03 & $2.85, .05^{*}$ \\
\hline Clear presentation: & $-.17^{*}$ & -.02 & .II & $2.47, .05^{*}$ \\
\hline $\begin{array}{l}\text { Reasonable } \\
\text { workload: }\end{array}$ & -.06 & $.17^{*}$ & .14 & $2.73, .05^{*}$ \\
\hline Interactive style: & $.21^{*}$ & .09 & $-.2 I^{*}$ & $3.07, .06^{*}$ \\
\hline Warm personality: & .04 & -.01 & -.14 & $0.91, .02$ \\
\hline Good feedback: & $.20^{*}$ & .00 & -.12 & $1.93, .04$ \\
\hline
\end{tabular}

Note. $\dagger p<.07,{ }^{*} p<.05,{ }^{* *} p<.01,{ }^{* * *} p<.001$.

qualify as necessities to students pursuing mastery goals. These same students also spent increasingly more of their Luxury budget than their Necessity budget on Clarity about How to Succeed and Reasonable Workload (Spending Change $\beta \mathrm{s}=.26$ and .17 , respectively), thus designating each as luxuries. Pursuit of mastery goals was unrelated to spending on the remaining instructor qualities. 
Finally, there was no compelling evidence for multiple goal effects. Across all of these analyses, only one of the Mastery X Performance interaction effects was significant; it predicted change in spending on an Interactive Teaching Style $(\beta=-.21)$. Simple slope analyses show that performance goals predicted an increase in spending on this quality only if the students did not pursue a mastery goal, $t(153)=2.89, p>.01, \beta=.38$. Among students who strongly pursued the mastery goal, performance goals had no impact on their spending on this quality, $t(153)=0.48, p>.05, \beta=.04$. Thus, students considered an interactive teaching style a luxury item if they pursued the performance goal alone instead of alongside a mastery goal.

\section{Discussion}

Students' ratings of instruction have been a prominent research topic for decades, much of it concerned with unveiling the different dimensions of teaching effectiveness (Marsh \& Roche, 1997). One recurring question is, which teacher qualities do students prize most? Prior research has generated a lengthy list of candidates (see Feldman, 1976), but little convergence on the answer (Abrami,1989).

The current study offers potential insight into this issue. We used a budget methodology that, unlike standard rating and ranking procedures, is specifically designed to distinguish necessities from luxuries. The spending patterns of the students in this sample reveal that they prioritized teachers who are energetic, passionate, humorous, and engaging (i.e., Enthusiasm and Entertainment), similar to prior work on evaluations of actual instructors (Feldman, 1976). They also clearly considered Topic Expertise, skill at conveying How to Succeed (i.e., what material is vital, how to approach studying), a Clear Presentation Style (i.e., good examples and summaries, and a style that facilitates effective note taking), and a Reasonable Workload to be fairly necessary qualities as well. By contrast, their spending patterns suggest they considered three other teacher qualities to be mere luxury items: being Warm/Compassionate (i.e., friendly, approachable, caring), using an Interactive Teaching Style that encourages discussion and different viewpoints, and providing Good Feedback to students

However, it is unlikely that all students agree about which instructor qualities are most important (Olivares, 2003). Any instructor quality may be a necessity to one student, a mere luxury to another. Students' academic motivation may be particularly important in shaping their beliefs about teacher effectiveness. To date, the relevant theorizing about motivation and teaching evaluations has been limited largely to students' interest or performance expectations, each of which predicts favourable teaching evaluations (see Feldman, 1976; Marsh, 1984). Our study instead examined whether students' achievement goals colour their beliefs about effective teaching. The results suggest they do. As expected, the spending patterns indicate that performance-focused students prioritize teachers who present topics in a clear manner and provide cues about how to succeed, whereas mastery-focused students prioritize teachers who possess high topic expertise and skill at challenging students intellectually.

These findings conceptually overlap with a few studies (Entwistle \& Tait, 1990; Vermetten, Vermunt, \& Lodewijks, 2002; Zhang, 2004) showing that students who use deeper learning strategies and engage in self-regulation (e.g., mastery-focused students) crave less structured guidance and greater independence from instructors than do students who use shallow learning strategies and engage in external regulation (e.g., performance-focused students). The findings for mastery goals also conceptually 
replicate work by Remedios and Lieberman (2008), who, in the lone previous study of achievement goals and instructor ratings, found positive links between mastery goals, interest, and favourable ratings of instructors.

These different relationships between the two goals and teacher preferences also support recent theorizing about how the two goals may lead students to pursue distinct learning agendas (Senko \& Miles, 2008). Attaining performance goals in one's coursework often requires outperforming most classmates, typically on lofty criteria determined by the teacher (Dweck \& Elliott, 1983). This might be why performance-focused students have been shown to attend closely to instructor cues and suggestions about which topics to study and how to study them (Senko \& Miles, 2008; Shell \& Husman, 2008; Vermetten, Lodewijks, \& Vermunt, 2001), a tactic conducive to high achievement when done properly (Broekkamp \& van Hout-Wolters, 2007; Diseth \& Martinsen, 2003). By contrast, attaining mastery goals is often a more subjective enterprise, typically with the student determining the criteria for judging success. Thus, mastery goal attainment may generally be more negotiable than performance goal attainment (Dweck \& Elliott, 1983). This might be why mastery-focused students, though often eager to please and have positive relations with their teachers (Darnon, Dompnier, Delmas, Pulfrey, \& Butera, 2009; Patrick, Ryan, \& Kaplan, 2007), are less prone to rely on instructor cues when studying (Shell \& Husman, 2008; Vermetten et al., 2001). They instead appear to approach their studying foremost with the desire to satisfy their own intellectual curiosities (Senko \& Miles, 2008). The current findings further substantiate the learning agenda premise by showing that performance-focused and mastery-focused students prize teachers who facilitate the successful pursuit of their respective agendas. Additionally, it is noteworthy that neither of the goals predicted spending on Enthusiasm/Entertainment in the Necessity budget. Rather, all students, regardless of goal, considered this quality a necessity, which is consistent with the high ranking often given to this quality in instructor evaluations (see Feldman, 1976).

One obvious next step is to test if our findings generalize to students' judgments of actual instructors. We assume they do. Students' descriptions of their ideal professor and of their best professors generally converge (see Feldman, 1976) because their judgments about the ideal professor are shaped by their prior experience with actual instructors (d'Apollonia \& Abrami, 1997). Nonetheless, the issue merits direct testing in real classes. We expect such studies to show that ratings of overall teaching effectiveness depend on the fit between the student's goal and the teacher's qualities: the teacher's skill at evoking and sustaining interest would be paramount for mastery-focused students, whereas the teacher's clarity, and perhaps also the student's anticipated grade, would be paramount for performance-focused students. We suspect as well that struggling students might give greater weighting than did our sample to teachers who provide good feedback or who show warmth and compassion to students. Finally, we recommend research into students' evaluations of instructors who use a self-directed learning approach (Rogers \& Freiberg, 1994). We did not test this possibility because selfdirected learning is uncommon and unfamiliar to most students at our university. We suspect, though, that mastery-focused students would prize autonomy-support alongside the interest-enhancing instructor qualities spotlighted in the current research.

Students recognize that pursuing mastery goals will please their teacher, and the effects of mastery goals may depend on whether they are pursued out of pure interest in mastery or out of a desire to create a positive impression (Darnon et al., 2009; Dompnier, Darnon, \& Butera, 2009). It is important, therefore, to consider whether our participants' 
mastery goals were genuine or 'fake'. We assume their goals were genuine because participants self-reported them anonymously; there was no opportunity to impress the research team by inflating their goal endorsement. Nor do our mastery goal findings provide any evidence of self-presentational concerns. Indeed, if self-presentational desires were driving the mastery-focused students' choices in this study, then they most likely would have spent their Necessity budget on instructor qualities that best promote positive teacher-student relationships: for example, an interactive teaching style because it provides opportunities to impress teachers during class, or a warm/compassionate personality because it provides reassuring opportunities to ingratiate themselves to teachers. The results instead showed that mastery-focused students sought foremost to be intellectually challenged.

\section{Conclusion}

This study makes three broad contributions. The first is its budget methodology. Compared to traditional rating and ranking procedures, it may allow more precise insight into students' beliefs about the most vital instructor qualities. Future research may benefit from continued use of this method. The study's second contribution is that it unveils the bidirectional link between students' goals and instructor practices. Many studies have explored this link with the perspective that instructor practices can create classroom climates that affect students' goals. The current findings suggest that students' goals may also influence their perceptions about the instructor's qualities and effectiveness. The study's final contribution is that it further supports the emerging theoretical premise that mastery goals and performance goals lead students to pursue largely different learning agendas, with distinct consequences to their learning experience.

\section{References}

Abrami, P. C. (1989). How should we use student ratings to evaluation teaching? Research in Higher Education, 30, 221-227.

Ames, C. (1992). Classrooms: Goals, structures, and student motivation. Journal of Educational Psychology, 84(3), 261-271. doi:10.1037/0022-0663.84.3.261

Barron, K. E., \& Harackiewicz, J. M. (2001). Achievement goals and optimal motivation: Testing multiple goal models. Journal of Personality and Social Psychology, 80, 706-722. doi:10.1037/0022-3514.80.5.706

Bong, M. (2005) Within-grade changes in Korean girls' motivation and perceptions of the learning environment across domains and achievement levels. Journal of Educational Psychology, 97, 656-672. doi:10.1037/0022-0663.97.4.656

Bouffard, T., Vezeau, C., \& Bordeleau, L. (1998). A developmental study of the relation between combined learning and performance goals and students' self-regulated learning. British Journal of Educational Psychology, 68, 321-330.

Broekkamp, H., \& van Hout-Wolters, B. H. A. M. (2007). Students' adaptation of study strategies when preparing for classroom tests. Educational Psychology Review, 19, 401-428.

d'Apollonia, S., \& Abrami, P. C. (1997). Navigating student ratings of instruction. American Psychologist, 52, 1198-1208. doi:10.1037/0003-066X.52.11.1198

Darnon, C., Dompnier, B., Delmas, F., Pulfrey, C., \& Butera, F. (2009). Achievement goal promotion at university: Social desirability and social utility of mastery and performance goals. Journal of Personality and Social Psychology, 96, 119-134. doi:10.1037/a0012824 
Diseth, A., \& Martinsen, O. (2003). Approaches to learning, cognitive style, and motives as predictors of academic achievement. Educational Psychology, 23, 195-207. doi:10.1080/01443410303225

Dompnier, B., Darnon, C., \& Butera, F. (2009). Faking the desire to learn: A clarification of the link between mastery goals and academic achievement. Psychological Science, 20, 939-943. doi:10.1111/j.1467-9280.2009.02384.x

Dweck, C. S., \& Elliott, E. S. (1983). Achievement motivation. In P. H. Mussen (Gen. Ed.) \& E. M. Hetherington (Vol. Eds.), Handbook of child psychology: Vol. IV. Social and personality development (pp. 643-691). New York: Wiley.

Elliot, A. J. (2005). A conceptual history of the achievement goal construct. In A. J. Elliot \& C. S. Dweck (Eds.), Handbook of competence and motivation (pp. 52-72). New York, NY: Guilford Publications.

Elliot, A. J., \& McGregor, H. A. (2001). A $2 \times 2$ achievement goal framework. Journal of Personality and Social Psychology, 80, 501-519. doi:10.1037/0022-3514.80.3.501

Elliot, A. J., McGregor, H. A., \& Gable, S. (1999). Achievement goals, study strategies, and exam performance: A mediational analysis. Journal of Educational Psychology, 91, 549-563.

Elliot, A. J., \& Murayama, K. (2008). On the measurement of achievement goal: Critique, illustration, and application. Journal of Educational Psychology, 100, 613-628. doi:10.1037/00220663.100.3.613

Entwistle, N. J., \& Tait, H. (1990). Approaches to learning, evaluations of teaching, and preferences for contrasting academic environments. Higher Education, 19, 169-194.

Escribe, C., \& Huet, N. (2005). Knowledge accessibility, achievement goals, and memory strategy maintenance. British Journal of Educational Psychology, 75, 87-104. doi:10.1348/000709904X19227

Feldman, K. A. (1976). The superior college teacher from the students' view. Research in Higher Education, 5, 243-288.

Feldman, K. A. (1988). Effective teaching from the students' and faculty's view: Matched or mismatched priorities? Research in Higher Education, 28, 291-344.

Ford, M. E. (1992). Motivating humans: Goals, emotions, and personal agency beliefs. Newbury Park, CA: Sage Publications, Inc.

Grant, H., \& Dweck, C. S. (2003). Clarifying achievement goals and their impact. Journal of Personality and Social Psychology, 85, 541-553. doi:10.1037/0022-3514.85.3.541

Greenwald, A. G., \& Gillmore, G. M. (1997a). Grading leniency is a removable contaminant of student ratings. American Psychologist, 52, 1209-1217. doi:10.1037/0003-066X.52.11.1209

Greenwald, A. G., \& Gillmore, G. M. (1997b). No pain, no gain? The importance of measuring course workload in student ratings of instruction. Journal of Educational Psychology, 89, 743-751. doi:10.1037/0022-0663.89.4.743

Harackiewicz, J. M., Durik, A. M., Barron, K. E., Linnenbrink-Garcia, E. A., \& Tauer, J. M. (2008). The role of achievement goals in the development of interest: Reciprocal relations between achievement goals, interest and performance. Journal of Educational Psychology, 100, 105122. doi:10.1037/0022-0663.100.1.105

Harris, A., Yuill, N., \& Luckin, R. (2008). The influence of context-specific and dispositional achievement goals on children's paired collaborative interaction. British Journal of Educational Psychology, 78, 355-374. doi:10.1348/000709907X267067

Hidi, S., \& Renninger, K. A. (2006). The four-phase model of interest development. Educational Psychologist, 41, 111-127. doi:10.1207/s15326985ep4102_4

Hulleman, C. S., Schrager, S. M., Bodmann, S. M., \& Harackiewicz, J. M. (2010). A meta-analytic review of achievement goal measures: Different labels for the same constructs or different constructs with similar labels? Psychological Bulletin, 136, 422-449. doi:10.1037/a0018947

Judd, C. M. (2000). Everyday data analysis in social psychology: Comparisons of linear models. In H. T. Reis \& C. M. Judd (Eds.), Handbook of research methods in social and personality psychology (pp. 370-393). New York, NY: Cambridge University Press. 
Karabenick, S. A. (2003). Seeking help in large college classes: A person-centered approach. Contemporary Educational Psychology, 28, 37-58. doi:10.1016/S0361-476X(02)00012-7

Li, N., Kenrick, D., Bailey, J., Linsenmeier, J. (2002). The necessities and luxuries of mate preferences: Testing the tradeoffs. Journal of Personality and Social Psychology, 82, 947-955. doi:10.1037/0022-3514.82.6.947

Marsh, H. W. (1984). Students' evaluations of university teaching: Dimensionality, reliability, validity, potential biases, and utility. Journal of Educational Psychology, 76, 707-764. doi:10.1037/0022-0663.76.5.707

Marsh, H. W. (1991). Multidimensional students' evaluations of teaching effectiveness: A test of alternative higher-order structures. Journal of Educational Psychology, 83, 285-296. doi:10.1037/0022-0663.83.2.285

Marsh, H. W., \& Roche, L. A. (1997). Making students' evaluations of teaching effectiveness effective: The critical issues of validity, bias, and utility. American Psychologist, 52, 11871197. doi:10.1037/0003-066X.52.11.1187

McKeachie, W. J. (1997). Student ratings: The validity of use. American Psychologist, 52, 12201225. doi:10.1037/0003-066X.52.11.1218

Moller, A. C., \& Elliot, A. J. (2006). The $2 \times 2$ achievement goal framework: An overview of empirical research. In A. Mittel (Ed.), Focus on educational psychology (pp. 307-326). New York: Nova Science Publishers, Inc.

Murphy, K. R., Cleveland, J. N., Skattebo, A. L., \& Kinney, T. B. (2004). Raters who pursue different goals give different ratings. Journal of Applied Psychology, 89, 158-164. doi:10.1037/00219010.89.1.158

Nicholls, J. G. (1984). Achievement motivation: Conceptions of ability, subjective experience, task choice, and performance. Psychological Review, 91, 328-346. doi:10.1037/0033295X.91.3.328

Olivares, O. J. (2003). A conceptual and analytic critique of student ratings of teachers in the USA with implications for teacher effectiveness and student learning. Teaching in Higher Education, 8, 233-245. doi:10.1080/1356251032000052465

Patrick, H., Ryan, A. M., \& Kaplan, A. (2007). Early adolescents' perceptions of the classroom social environment, motivational beliefs, and engagement. Journal of Educational Psychology, 99, 83-98. doi:10.1037/0022-0663.99.1.83

Payne, S. C., Youngcourt, S. S., \& Beaubien, J. M. (2007). A meta-analytic examination of the goal orientation nomological net. Journal of Applied Psychology, 92, 128-150. doi:10.1037/00219010.92.1.128

Pekrun, R., Elliot, A. J., \& Maier, M. A. (2006). Achievement goals and discrete achievement emotions: A theoretical model and prospective test. Journal of Educational Psychology, 98, 583-597. doi:10.1037/0022-0663.98.3.583

Pintrich, P. (2000). An achievement goal theory perspective on issues in motivation terminology, theory, and research. Contemporary Educational Psychology, 25, 92-104. doi:10.1006/eps.1999.1017

Poortvliet, P. M., Janssen, O., Van Yperen, N. W., \& Van de Vliert, E. (2007). Achievement goals and interpersonal behavior: How mastery and performance goals shape information exchange. Personality and Social Psychology Bulletin, 33, 1435-1447. doi:10.1177/0146167207305536

Remedios, R., \& Lieberman, D. A. (2008). I liked your course because you taught me well: The influence of grades, workload, expectations and goals on students' evaluations of teaching. British Educational Research Journal, 34, 91-115. doi:10.1080/01411920701492043

Rogers, C. R., \& Freiberg, J. (1994). Freedom to learn (3rd ed.). New York, NY: Merrill/Macmillan College Publishing Co.

Senko, C., Hulleman, C. S., \& Harackiewicz, J. M. (2011). Achievement goal theory at the crossroads: Old controversies, current challenges, and new directions. Educational Psychologist, 46, 2647. doi:10.1080/00461520.2011.538646 
Senko, C., \& Miles, K. M. (2008). Pursuing their own learning agenda: How mastery-oriented students jeopardize their class performance. Contemporary Educational Psychology, 33, 561583. doi:10.1016/j.cedpsych.2007.12.001

Shell, D. F., \& Husman, J. (2008). Control, motivation, and strategic self-regulation in the college classroom: A multidimensional phenomenon. Journal of Educational Psychology, 100, 443459. doi:10.1037/0022-0663.100.2.443

Sideridis, G. D. (2009). Normative vs. non-normative performance goals: Effects on behavioral and emotional regulation in achievement situations. In M. Wosnitza, S. A. Karabenick, A. Efklides, \& P. Nenniger (Eds.), Contemporary motivation research: From global to local perspectives (pp. 321-338). Ashland, OH: Hogrefe \& Huber Publishers.

Van Yperen, N. W., Hamstra, M. R. W., \& van der Klauw, M. (2011). To win, or not to lose, at any cost: The impact of achievement goals on cheating. British Journal of Management, 22, S5-S15. doi:10.1111/j.1467-8551.2010.00702.x

Vermetten, Y. J., Lodewijks, H. G., \& Vermunt, J. D. (2001). The role of personality traits and goal orientations in strategy use. Contemporary Educational Psychology, 26, 149-170. doi:10.1006/ceps.1999.1042

Vermetten, Y. J., Vermunt, J. D., \& Lodewijks, H G. (2002). Powerful learning environments? How university students differ in their response to instructional measures. Learning and Instruction, 12, 263-284. doi:10.1016/S0959-4752(01)00013-5

Wolters, C. A. (1998). Self-regulated learning and college students' regulation of motivation. Journal of Educational Psychology, 90, 224-235. doi:10.1037/0022-0663.90.2.224

Zhang, L-F. (2004). Do university students' thinking styles matter in their preferred teaching approaches? Personality and Individual Differences, 37, 1551-1564. doi:10.1016/j.paid.2004.02.012

Received 19 July 2010; revised version received II March 201 I 
Copyright of British Journal of Educational Psychology is the property of Wiley-Blackwell and its content may not be copied or emailed to multiple sites or posted to a listserv without the copyright holder's express written permission. However, users may print, download, or email articles for individual use. 